The Israeli Journal of Aquaculture - Bamidgeh, IJA_69.2017.1391, 7 pages

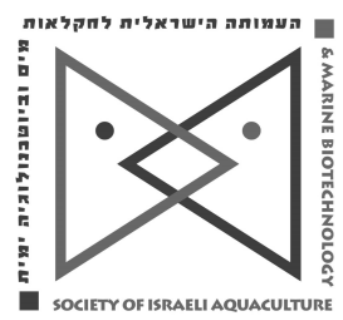

The IJA appears exclusively as a peer-reviewed on-line open-access journal at http://www.siamb.org.il. To read papers free of charge, please register online at registration form.

Sale of $I J A$ papers is strictly forbidden.

\title{
Replacement of Soybean Meal with Rhizoclonium riparium Protein Concentrate in the Diet of Pacific White Shrimp Litopenaeus vannamei Postlarvae
}

\author{
Augusto E. Serrano, Jr. ${ }^{1 *}$, Ritche S. Declarador ${ }^{2}$, Mary Grace C. \\ Sedanza ${ }^{2}$, Barry Leonard M. Tumbokon ${ }^{1}$
}

${ }^{1}$ National Institute of Molecular Biology and Biotechnology, University of the Philippines Visayas, Miagao, Iloilo, Philippines

${ }^{2}$ Institute of Aquaculture, College of Fisheries and Ocean Sciences, University of the Philippines Visayas, Miagao, Iloilo, Philippines

Keywords: chlorophyte; seaweed growth promoting effect; body composition effects of seaweed

\begin{abstract}
The biological value of incorporating Rhizoclonium riparium var. implexum protein concentrate (RPC) meal in the diet of Pacific white shrimp Litopenaeus vannamei, postlarvae was evaluated for 60 days. Four diets were prepared: no seaweed inclusion ( $0 \%$, control diet), $5.25 \%$ seaweed inclusion, $10.5 \%$ seaweed inclusion, and $15.75 \%$ seaweed inclusion with equivalent replacement rates of soybean meal at $0,15 \%, 30 \%$ and $45 \%$. Final average body weight (FABW) and weight gain (WG) of the shrimp were not significantly affected by the RPC supplementation $(P>0.05)$ except those of shrimp fed the highest level of $15.75 \%$ RPC, which showed lower values but were statistically similar to those of the $5.25 \%$ group. Specific growth rate (SGR) and protein gained (PG) values of shrimp were not affected by the dietary RPC except those of the $15.75 \%$ group, which showed significantly lower values. Neither feed conversion efficiency (FCE) nor protein efficiency ratio (PER) showed a clear trend for graded concentration of RPC. Survival of shrimp was relatively good and statistically similar ranging from $76.0 \%-$ $84.0 \%$. In conclusion, Rhizoclonium protein concentrate can replace $30 \%$ soybean meal in the diet of Penaeus vannamei postlarvae or an equivalent of $10.5 \%$ inclusion rate without negative effects on the survival, growth, and feed conversion efficiency of white shrimp.
\end{abstract}

* Augusto E. Serrano, Jr. e-mail: aeserrano@up.edu.ph 


\section{Introduction}

Protein sources in the animal feed industry contain more than $20 \%$ crude protein. Green seaweeds contain less than this amount: $9.9 \%$ in Enteromorpha (Ulva) intestinalis (Serrano and Aquino, 2014), 13.4\% in Ulva lactuca (Santizo et al 2014), 13.93\% and $15.6 \%$ d.w. in Rhizoclonium riparium var implexum (Cabanero et al 2015 and Sedanza and Serrano 2016, respectively). However, protein content can be improved by acid precipitation to $38.4 \%$ in Ulva lactuca (Santizo et al 2014), 31.6\% in Enteromorpha (Ulva) intestinalis (Serrano and Aquino 2014). The concentration of crude protein in Rhizoclonium riparium var implexum was increased from $15.55 \%$ d.w. to $23.9 \%$ d.w. by solid state fermentation (Sedanza 2016). The chemical score (CS) and essential amino acid index (EAAI) of Rhizoclonium riparium protein concentrate (RPC) as a feed ingredient for penaeid shrimp is estimated to be 64 and $105 \%$ of shrimp EAA requirement, respectively (Serrano 2016). The EAAI indicates well-balanced essential amino acids with $100 \%$ of EAA requirement as a perfect score. In contrast, the CS reveals that when used as the sole source of protein, RPC can only support growth at $64 \%$ of its theoretical maximal growth (Serrano 2016); its most limiting amino acid was lysine. Soybean meal itself is deficient in methionine, threonine, and lysine in this order (Berry et al 1962). Thus, soybean itself can replace the deficiency of RPC together only with other protein sources in the diet of penaeid shrimp.

RPC has been evaluated in Nile tilapia Oreocromis niloticus (Cabanero et al., 2015a, b) but has not yet been studied in shrimp. The objective of this study was to evaluate crinklegrass Rhizoclonium riparium var implexum protein concentrate as an ingredient to replace soybean meal the diet of Pacific white shrimp Litopenaeus vannamei.

\section{Materials and Methods}

Collection and preparation of Rhizoclonium riparium. Rhizoclonium riparium var. implexum (Dillwyn) Kützing (1843) was previously identified by Dr. Anicia Q. Hurtado Ponce, an expert in macroalgae identification in the Philippines (Bunda et al., 2015a). The seaweed was collected from brackish water ponds of the Brackishwater Aquaculture Center (BAC) of the Institute of Aquaculture, College of Fisheries and Ocean Sciences (CFOS-IA), University of the Philippines Visayas (UPV) in Brgy. Nabitasan, Leganes, Iloilo and transported to the Multi-Species Hatchery of CFOS-IA, UPV in Miagao, Iloilo for processing.

Protein concentrate of the seaweed was prepared following a modified method of Virabalin et al (1993) which included an acidification stage. Dried Rhizoclonium seaweed was homogenized with distilled water using a mechanical juicer. The slurry was acidified by adding $\mathrm{HCL}$ to $\mathrm{pH} 3.0$, heated to $90^{\circ} \mathrm{C}$ for $20 \mathrm{~min}$ and the coagulated protein filtered through a muslin cloth. The thick protein concentrate slurry was oven-dried to about $10 \%$ moisture, ground into fine powder using a coffee grinder (KRUPS F203) and was kept at $-20^{\circ} \mathrm{C}$ until further use.

A control and 3 test diets with different levels of inclusion of RM for Pacific white shrimp were formulated following Bunda (2015) (see Table 1) at the Nutrition Laboratory of the Institute of Aquaculture, University of the Philippines Visayas (UPV). Before mixing, all ingredients were passed through a $150 \mu \mathrm{m}$ sieve. All ingredients were mechanically mixed, pelleted and oven-dried for $8-12 \mathrm{~h}$ at $60^{\circ} \mathrm{C}$. The pellets were then sieved to a size of $4 \mathrm{~mm}$ and stored in polyethylene bags at $-20^{\circ} \mathrm{C}$ until use. 
Table 1. Ingredient and proximate composition of the Rhizoclonium riparium var implexum protein concentrate experimental diets fed to the Pacific white shrimp (Penaeus vannamei) postlarvae.

\begin{tabular}{lllll}
\hline & $0 \%$ & $5.25 \%$ & $10.50 \%$ & $15.75 \%$ \\
& $R P C$ & $R P C$ & $R P C$ & $R P C$ \\
\hline Danish fish meal & 250.00 & 250.00 & 250.00 & 250.00 \\
Squid meal & 29.00 & 29.00 & 29.00 & 29.00 \\
Soybean meal & 350.00 & 297.50 & 245.00 & 192.50 \\
Bread flour & 117.00 & 117.00 & 117.00 & 117.00 \\
Cod liver oil & 63.00 & 63.00 & 63.00 & 63.00 \\
Lecithin & 5.00 & 5.00 & 5.00 & 5.00 \\
Carboxy Methyl Cellulose & 130.50 & 130.50 & 130.50 & 130.50 \\
Lignobond & 15.00 & 15.00 & 15.00 & 15.00 \\
Vitamin mix* & 10.00 & 10.00 & 10.00 & 10.00 \\
Mineral mix & 10.00 & 10.00 & 10.00 & 10.00 \\
Dicalphosphate & 20.00 & 20.00 & 20.00 & 20.00 \\
BHT & 0.50 & 0.50 & 0.50 & 0.50 \\
Rhizoclonium Protein Conc. & 0.00 & 52.50 & 105.00 & 157.50 \\
Total & 1000.0 & 1000.0 & 1000.0 & 1000.0 \\
\hline Dry matter & 10.12 & 11.85 & 10.61 & 9.18 \\
Crude protein & 35.96 & 34.28 & 33.48 & 32.36 \\
Crude lipid & 9.20 & 8.37 & 9.08 & 8.21 \\
Crude fiber & 2.56 & 2.64 & 3.01 & 2.69 \\
Ash & 12.09 & 14.63 & 17.37 & 21.07 \\
NFE & 32.63 & 30.87 & 29.46 & 29.18 \\
Total & 100.0 & 100.0 & 100.0 & 100.0 \\
\hline
\end{tabular}

*Vitamin mix: Vitamin A, $1200000 \mathrm{IU} / \mathrm{kg}$; Vitamin $\mathrm{D}_{3}, 200000 \mathrm{IU} / \mathrm{kg}$;

Vitamin E, $20000 \mathrm{IU} / \mathrm{kg}$; Vitamin $B_{1}, 8000 \mathrm{mg} / \mathrm{kg}$; Vitamin $B_{2}, 8000 \mathrm{mg} / \mathrm{kg}$; Vitamin $B_{6}, 5000 \mathrm{mg} / \mathrm{kg}$; Vitamin $\mathrm{B}_{12} 1 \%, 2000$ $\mathrm{mcg} / \mathrm{kg}$; Niacin, 40000 $\mathrm{mg} / \mathrm{kg}$; Calcium Pantothenate, 20000 $\mathrm{mg} / \mathrm{kg}$; Biotin, $40 \mathrm{mg} / \mathrm{kg}$; Folic Acid, $1800 \mathrm{mg} / \mathrm{kg}$; Ethoxyquin, $500 \mathrm{mg} / \mathrm{kg}$

Growth trial. Two thousand $P$. vannamei post larvae shrimp from a commercial shrimp hatchery in Guimbal, Iloilo were nursed in a 1ton capacity tank at the University of the Philippines

Visayas Multi-Species Hatchery. The shrimp were acclimated and fed a commercial diet for 2 weeks. Before the experiment, the shrimp were randomly selected and screened, in the Fish Disease Laboratory of SEAFDEC, by one-step PCR for WSSV detection and were found to be virus free.

The growth trial was conducted using a recirculating system annexed to a sedimentation tank filtered by layers of cotton fiber, a biological filter containing oyster empty shells and mechanical filter tanks i.e., containing sand and gravel. The water was recirculated from the series of filter tanks to the $50 \mathrm{~L}$ capacity aquaria at a flow rate of about $600 \mathrm{ml} / \mathrm{min} /$ tank. Salinity ranged between 25-27ppt, temperature between 25$27^{\circ} \mathrm{C}, \mathrm{pH}$ between 8.5-9.0 and dissolved oxygen was maintained at $>5 \mathrm{ppm}$. These were monitored weekly. Nitrite $(0-0.015 \mathrm{ppm})$ and total ammonia-nitrogen (TAN) that ranged between 0-0.02 were measured with commercially available kits (CP Aqua Test kits) and maintained at a low level by $100 \%$ water replacement in the recirculating system every 5-7 days. Each aquarium was provided with adequate aeration and cleaned daily by siphoning uneaten feed and feces before feeding.

Five hundred post larvae shrimps $(0.06 \pm 0.02 \mathrm{~g})$ were distributed randomly into 20 substrate-free $50 \mathrm{~L}$ culture tanks while the rest $(1,500$ post larvae) were sacrificed for the initial body composition. The shrimp were further acclimated to the experimental condition and to the control diet for 5 days. Four replicates of the experimental diets containing varying levels of the RPC, namely, $0 \%$ (control), $5.25 \%, 10.50 \%$ and $15.75 \%$ were fed to the shrimp in a completely randomized design. Feed was administered three times daily $(08: 00,12: 00$ and $16: 00)$ for 60 days and at a ration starting at $20 \%$ of average wet body weight and decreased to $6 \%$ towards the end of the experimental period. Sampling was conducted at the beginning of the experiment and every 15 days thereafter and shrimp from each tank were counted and bulk-weighed.

Growth measurement. The parameters measured were weight gain (WG), specific growth rate (SGR), protein efficiency ratio (PER), percent survival, feed conversion efficiency (FCE) and protein gained (PG). These were calculated using the following formulas: 


$$
\begin{gathered}
\text { WG }(\mathrm{g})=\mathrm{FBW}-\mathrm{IBW} \\
\text { SGR }(\% / \text { day })=100 *(\mathrm{LnFBW}-\mathrm{LnIBW}) / \mathrm{D} \\
\% \mathrm{FCE}=100 *(\mathrm{FBW}-\mathrm{IBW}) / \mathrm{FI} \\
\mathrm{PG}(\mathrm{g})=(\mathrm{CP} \times \mathrm{FBW})-(\mathrm{CP} \times \mathrm{IBW}) \times 100 \\
\mathrm{PER}=(\mathrm{FBW}-\mathrm{IBW}) /(\mathrm{FI} \times \mathrm{FP}) \\
\text { Survival, } \%=100 * \text { Final count of shrimps/Initial count of shrimps }
\end{gathered}
$$

Where: FBW = final body weight $(\mathrm{g})$ of individual fish; $\mathrm{D}=$ days of culture; IBW = initial body weight $(\mathrm{g})$ of individual fish; $\mathrm{FP}=$ Feed Protein (in decimal); $\mathrm{CP}_{\mathrm{i}}=$ Initial carcass protein (in decimal); $\mathrm{CP}_{\mathrm{f}}=$ Final carcass protein (in decimal); $\mathrm{FI}=$ total feed intake of individual fish for the whole duration of the experiment

Analytical Methods and Calculations. Samples of the diets were submitted to Oversea Feeds Laboratory in San Fernando, Cebu, Philippines for proximate analysis (AOAC, 1990). Shrimp body composition analysis for dry matter, crude protein, and crude fat analysis (AOAC, 1990) were conducted in the laboratories of the Institute of Aquaculture and the Institute of Fish Processing Technology (CFOS-IFPT), University of the Philippines Visayas (UPV). All analyses were carried out in triplicate. Dry matter was determined by placing the sample in a constant weight crucible and dried in an oven at $100^{\circ} \mathrm{C}$. Determination of crude fat was done using Foss $®$ Soxtec 2055. Ash content was determined after incineration in a muffle furnace at $550^{\circ} \mathrm{C}$ for $12 \mathrm{~h}$. Crude protein was measured after block digestion and steam distillation using Kjeltec digestion system set at a temperature of $400^{\circ} \mathrm{C}$ and Foss KjeltecTM 8200 auto-distillation unit.

Statistical Analyses. Data are presented as mean \pm standard error of the mean (SEM) for each dietary treatment. They were analyzed using Levene's test for homogeneity of variances and Shapiro-Wilk test for normal distribution before using one-way analysis of variance (ANOVA). Tuckey test for mean separation was used to evaluate significant differences $(P<0.05)$ among treatment means.

\section{Results}

Growth and food conversion efficiency. Growth indices such as FABW, WG and SGR, food conversion efficiency (FCE, PER and $P G$ ) and survival rate of post larvae shrimp fed experimental diets are shown in Table 2. FABW and WG of shrimps were not significantly affected by the RPC supplementation $(P>0.05)$ except those of shrimps fed the highest level of $15.75 \%$ RPC which showed lower values which were statistically similar with those of the $5.25 \%$ group. Similarly, SGR and PG values of shrimps were not affected by the dietary RPC except those of the $15.75 \%$ group. FCE values, in contrast, revealed that the groups fed diets containing $0 \%$ and $10.5 \%$ were statistically similar but significantly higher than those in $5.25 \%$ and $15.75 \%$ groups. PER values were statistically similar in the control, $5.25 \%$ and $15.75 \%$ but lower than the values exhibited by the $10.5 \%$ RPC

\begin{tabular}{|c|c|c|c|c|c|c|c|}
\hline & \multicolumn{7}{|c|}{ Parameters } \\
\hline & $F A B W$ & $W G$ & $S G R$ & $F C E$ & $P E R$ & $P G$ & $\% S U R V$ \\
\hline $0 \% R P C$ & $1.30 \pm 0.17^{b}$ & $1.2 \pm 0.17^{b}$ & $5.1 \pm 0.227^{b}$ & $0.59 \pm 0.02^{b}$ & $1.6 \pm 0.06^{\mathrm{ab}}$ & $0.82 \pm 0.12^{b}$ & $78.0 \pm 6.2^{a}$ \\
\hline $5.25 \% R P C$ & $0.97 \pm 0.02^{a b}$ & $0.91 \pm 0.02^{a b}$ & $4.7 \pm 0.03^{b}$ & $0.51 \pm 0.02^{a}$ & $1.5 \pm 0.06^{a}$ & $0.63 \pm 0.01^{b}$ & $79.0 \pm 2.8^{a}$ \\
\hline $10.50 \% R P C$ & $1.10 \pm 0.03^{b}$ & $1.1 \pm 0.03^{b}$ & $5.0 \pm 0.05^{b}$ & $0.58 \pm 0.00^{b}$ & $1.7 \pm 0.01^{b}$ & $0.63 \pm 0.02^{b}$ & $76.0 \pm 1.6^{a}$ \\
\hline $15.75 \% R P C$ & $0.69 \pm 0.06^{a}$ & $0.63 \pm 0.06^{a}$ & $4.1 \pm 0.14^{a}$ & $0.49 \pm 0.01^{a}$ & $1.5 \pm 0.02^{a}$ & $0.44 \pm 0.04^{a}$ & $84.0 \pm 3.7^{a}$ \\
\hline
\end{tabular}
group. Both FCE and PER did not show a clear trend viz a viz the graded concentration of RPC. Survival of shrimp was relatively good and statistically similar with a mean range of $76.0 \%-84.0 \%$.

Table 2. Growth performance of Penaeus vannamei postlarvae fed experimental diets containing increasing levels of Rhizoclonium Protein Concentrate meal

Body composition. Whole body composition of shrimp fed the RPC supplemented and control diets are shown in Table 3. All the experimental groups of shrimp were statistically similar in body moisture, crude protein, and ash with the exception of body crude lipid which was significantly higher in shrimps fed the diet containing $15.75 \%$ RPC. 
Table 3. Whole body composition of post larvae Penaeus vannamei fed graded levels of Rhizoclonium riparium var implexum Protein Concentrate (RPC) meal.

\begin{tabular}{lllll}
\hline & Moisture & Crude Protein & Crude Lidid & Ash \\
\hline Initial carcass & $17.3 \pm 0.30$ & $56.6 \pm 2.2$ & $4.14 \pm 0.0$ & $3.9 \pm 0.04$ \\
\hline Control & $23.3 \pm 0.4^{\mathrm{a}}$ & $66.6 \pm 2.5^{\mathrm{a}}$ & $4.0 \pm 2.4^{\mathrm{a}}$ & $3.6 \pm 0.2^{\mathrm{a}}$ \\
$5.25 \%$ RPC & $22.8 \pm 0.7^{\mathrm{a}}$ & $68.1 \pm 1.6^{\mathrm{a}}$ & $3.1 \pm 0.1^{\mathrm{a}}$ & $3.6 \pm 0.2^{\mathrm{a}}$ \\
$10.50 \%$ RPC & $22.8 \pm 0.1^{\mathrm{a}}$ & $58.9 \pm 4.7^{\mathrm{a}}$ & $4.8 \pm 1.1^{\mathrm{a}}$ & $3.5 \pm 0.2^{\mathrm{a}}$ \\
$15.75 \%$ RPC & $20.9 \pm 0.4^{\mathrm{a}}$ & $68.6 \pm 1.7^{\mathrm{a}}$ & $11.8 \pm 0.0^{\mathrm{b}}$ & $3.8 \pm 0.1^{\mathrm{a}}$ \\
\hline
\end{tabular}

Values are expressed as mean \pm SEM. Mean values in columns with different superscript letters are significantly different $(P<0.05)$. Data presented as percent dry basis.

\section{Discussion}

It has been previously reported that RPC contains crude protein (23.94\%) and good essential amino acid index (1.1) which makes it a potential feed ingredient for aquafeeds (Sedanza \& Serrano 2016; Serrano 2016). The present study evaluated the biological value of protein concentrate of crinkle grass Rhizoclonium $s p$. Incorporating RPC at low levels (5.25\%-10.50\%) improved or did not negatively affect the growth performance and feed efficiency of Litopenaeus vannamei. However, significant negative effects on SGR, FCE and PG were observed when $15.75 \%$ RPC (i.e. $45 \%$ replacement of soybean meal) was incorporated in the shrimp diet. These results suggest the inclusion level favorable for shrimp growth is between $5.25 \%-10.50 \%$; however it was lower than that of the raw meal of Rhizoclonium which is as high as $15.75 \%$ not only for replacing soybean but also simultaneously replacing $100 \%$ of the mineral mix (Sedanza and Serrano 2016). This trend may be attributed to the process of concentrating proteins in the seaweed (Santizo et al., 2014; Kandasamy et al., 2012). Oxidized phenolic compounds may have reacted with the amino acids and proteins in the present study, inhibiting the activity of proteolytic enzymes and in turn lowering the nutritional value. Phenolic compounds lead to formation of insoluble/indigestible complexes with protein that interfere with its utilization (Wong and Cheung 2001). The findings of Santizo et al., (2014) showed similar results. The authors attribute these results to the small amounts of anti-nutrients found in the Ulva protein concentrate at higher inclusion level of $15.75 \%$ (i.e. $45 \%$ soybean meal replacement by weight in the diet); it could have led to the inferior growth performance of $P$. monodon. Another factor may be that due to the disproportionate amounts of amino acids found in the RPC diet. Although the EAAI of RPC was $110 \%$ of the shrimp's EAA requirement based on our recent findings, the chemical score was only $64 \%$ with lysine as the first limiting EAA (Serrano 2016). This means that RPC can only supply $64 \%$ of lysine required by the Pacific white shrimp and that the difference needs to be supplemented in the diet. The process of concentrating protein from $R$. riparium in the present study using both $\mathrm{pH}$ shift and heat treatment might have destroyed some of the lysine which is known to reduce the oxidation of other amino by improving the use of other EAAs (Kerr and Kerster, 1985). The remaining lysine in the present study resulted in lower than expected growth rate.

Although the results of this study showed that reduced growth and feed efficiency occurred at the highest inclusion rate, no other adverse effects were observed. Survival rate and the carcass composition, except for crude lipid content, did not vary significantly among all treatments. A high carcass lipid increase was observed at the highest inclusion level. The composition of dietary lipid affects that of the carcass lipid (Molina-Poveda, 2016). Pearson correlation analysis of the lipid content of the diet and that of carcass showed a similar trend in which an increased amount of dietary lipid linearly increased that of carcass. As amino acids cannot be stored in the body for later use, any amino acid not required for immediate biosynthesis is deaminated, and the carbon skeleton is 
used as metabolic fuel or converted into fatty acids (FAs) via acetyl CoA (Molina- Poveda, 2016). The high amount of RPC inclusion might have exacerbated the already reduced lysine (Serrano 2016), which is a precursor of carnitine, a very important component in the transport of long-chain fatty acyl groups into the mitochondria for beta oxidation (Tanphaichitr et al., 1971).

In conclusion, RPC could be a substitute for soybean meal in the diet of Penaeus vannamei postlarvae up to $30 \%$ which is equivalent to $10.5 \%$ inclusion level, without compromising the survival, growth and feed utilization efficiency of the shrimp.

\section{Acknowledgements}

The authors wish to express their gratitude to the Philippine Department of Science and Technology (DOST)-Philippine Council for Agriculture, Aquatic and Natural Resources Development (PCAARRD) and DOST- Accelerated Science and Technology Human Resource Development Program (ASTHRDP). They also wish to thank the UPV Office of the Research and Extension for the partial research funding and publication support.

\section{References}

AOAC, 1990. Official Methods of Analysis of Association of Official Analytical Chemists. $15^{\text {th }}$ Ed. Arlington, VA.

Berry, T.H., Becker, D.E., Rasmussen, O.G., Jensen, A.H., Norton, H.W. 1962. The limiting amino acids in soybean protein. J. Anim. Sci., 21(3): 558-561.

Bunda M. G. B., Tumbokon B. L. M., Serrano Jr. A. E., 2015. Physical properties of Rhizoclonium meal as feed ingredient in aquafeeds. ABAH Bioflux, 7(1):79-86.

Bunda M.G.B., 2015. Properties of Rhizoclonium implexum as feed ingredient. M.Sc. Thesis, Institute of Aquaculture, College of Fisheries and Ocean Sciences, University of the Philippines Visayas. 91 pp.

Cabanero, P. C., Tumbokon, L. B. M., Serrano, Jr., A. E. 2016a. Nutritional evaluation of Rhizoclonium riparium var implexum meal to replace soybean in the diet of the Nile tilapia fry, 9 pages. IJA 68.2016.1278. 8 pages.

Cabanero, P. C., Tumbokon, L. B. M., Serrano, Jr., A. E., 2016b. Lysine supplementation of the Protein Concentrate of the crinkle grass Rhizoclonium riparium var implexum as an ingredient in the diet of the Nile tilapia fry, IJA 68.2016.1280. 7 pages.

Harper A. E., Benevenga N. J., Wohlhueter R. M., 1970 Effects of ingestion of disproportionate amounts of amino acids. Physiological Reviews 50: 428-458.

Kandasamy, G., Karuppiah, S. K., Rao, P. V. S., 2012. Salt- and pH- induced functional changes in protein concentrate of edible green seaweed Enteromorpha species. Fish. Sci., 78: 169-176.

Kerr B. J., Easter R. A., 1995 Effect of feeding reduced protein, amino acidsupplemented diets on nitrogen and energy balance in grower pigs. J. Anim. Sci., 73: 3000-3008.

Molina-Poveda C., 2016 Nutrient requirements. In: Aquafeed formulation. Nates S. F. (ed), Academic Press, pp. 75-216.

Santizo R., Serrano Jr. A. E., Corre V. L., 2014. Proximate composition and dry matter digestibility of Ulva lactuca in the black tiger shrimp Penaeus monodon. $A B A H$ Bioflux, 6(1): 75- 83.

Sedanza, M.G.C. 2016. Evaluation of raw, protein concentrate and fermented seaweed, Rhizoclonium riparium var implexum as feed ingredient in Pacific white shrimp, Penaeus vannamei. M.S. in Fisheries (Aquaculture) Thesis. University of the Philippines Visayas, Miagao, Iloilo, Philippines. 144 pages.

Sedanza, M.G.C., Serrano Jr., A.E. 2016. Evaluation of crinkle grass Rhizoclonium riparium in a diet for Pacific white shrimp Penaeus vannamei post larvae. IJA 68.2016.1328.

Serrano Jr., A.E., 2016. Evaluation of the chlorophyte Rhizoclonium spp. as feed ingredient in tilapia and shrimp. UPV In-house Research Terminal Report. University of the Philippines Visayas, Miagao, Iloilo, Philippines. 40 pages. 
Serrano Jr., A.E., Aquino, J.I.L. 2014. Protein concentrate of Ulva intestinalis (Chlorophyta, Ulvaceae) could replace soybean meal in the diet of Oreochromis niloticus fry. AACL Bioflux, 7(4): 255-262.

Tanphaichitr, V., Home, D. W., Broquist, H. P., 1971. Lysine, a precursor of carnitine in the rat. J. Biol. Chem., 246, 6364-6366.

Virabalin R., Kositsup B., Punnapayak H., 1993 Leaf protein concentrate from water hyacinth. J. Aquat. Plant Manage., 31: 207-209.

Wong K. H., Cheung P. C. K., 2001. Nutritional evaluation of some subtropical red and green seaweeds Part II. An in vitro protein digestibility and amino acid profile of protein concentrates. Food Chem., 72: 11- 17. 